\title{
PENGARUH EKSTRAK KLIKA ONGKEA (Mezzetia parviflora Becc.) TERHADAP KADAR INSULIN TIKUS WISTAR YANG DIINDUKSI STREPTOZOTOCIN
}

\section{EFFECT OF KLIKA ONGKEA EXTRACT (Mezzetia parviflora Becc.) ON THE INSULIN CONTENT OF THE WISTAR RATS INDUCED BY STREPTOZOTOCIN}

\author{
Jangga $^{1}$, Mawar $^{2}$ \\ ${ }^{1}$ Universitas Mega Rezky \\ ${ }^{2}$ Jurusan Analis Kesehatan Poltekkes Kemenkes Makassar
}

Koresponden: jangga.angga@yahoo.co.id

\begin{abstract}
ABSTRAK
Penelitian ini bertujuan untuk mengetahui pengaruh ekstrak klika ongkea (Mezzetia parviflora Becc.) terhadap kadar insulin tikus wistar yang diinduksi streptozotocin. Jenis penelitian ini adalah eksperimental dengan rancangan modifikasi pretest postest randomized controlled group design, dilaksanakan mulai bulan September sampai dengan Desember 2017, jumlah sampel sebanyak 120 ekor tikus wistar. Pemeriksaan kadar insulin dilakukan 5 kali, yaitu 1 kali sebelum diinduksi STZ dan 4 kali setelah diinduksi STZ, yaitu hari ke-1, ke-7, ke-14, ke-21 dan ke-28, Kelompok I diberikan larutan koloidal Na. CMC 1\%, kelompok II diinduksi STZ $40 \mathrm{mg} / \mathrm{kgBB}$ tikus, kelompok III diinduksi STZ $40 \mathrm{mg} / \mathrm{kgBB}$ tikus kemudian diberikan galvus $0,9 \mathrm{mg} / 200 \mathrm{kgBB}$ tikus, kelompok IV diinduksi STZ $40 \mathrm{mg} / \mathrm{kgBB}$ tikus kemudian diberikan suspensi ekstrak klika ongkea $100 \mathrm{mg} / \mathrm{kgBB}$ tikus, kelompok V diinduksi STZ $40 \mathrm{mg} / \mathrm{kgBB}$ tikus kemudian diberikan suspensi ekstrak klika ongkea $300 \mathrm{mg} / \mathrm{kgBB}$ tikus dan kelompok VI pada hari minus 2 diberikan suspensi ekstrak klika ongkea $300 \mathrm{mg} / \mathrm{kgBB}$ tikus kemudian diinduksi STZ 40 mg/kgBB tikus. Masing-masing kelompok pada hari ke-1, ke-7, ke-14, ke21 dan ke-28 dipuasakan terlebih dahulu kemudian diobservasi masing-masing 4 ekor. Data yang diperoleh dianalis dengan menggunakan uji $\mathrm{T}$ tidak berpasangan. Hasil penelitian menujukkan bahwa pemberian ekstrak klika ongkea berpengaruh terhadap kadar insulin, dan tidak ada perbedaan pengaruh pemberian dosis bertingkat ekstrak klika ongkea terhadap kadar insulin.
\end{abstract}

Kata kunci : ekstrak klika ongkea, insulin, streptozotocin

\section{PENDAHULUAN}

Saat ini telah banyak dikembangkan obat-obatan dari bahan alami untuk mengontrol diabetes mellitus, sebagian dari bahan-bahan tersebut telah diteliti dan terbukti efektif sebagai terapi alternatif
(Suharmiati, 2003; Murkhejee, et al. 2006; Ali, et al. 2009). Antioksidan banyak ditemukan dalam sayuran dan buah-buahan. Komponen yang bersifat antioksidan dalam sayuran dan buahbuahan meliputi vitamin $\mathrm{C}$, vitamin $\mathrm{E}$, Karoten, polifenol, flavanoid, flavon, 
antosianin, katekin, dan isokatekin (Kahkonen, et al. 2009), serta asam lipoat (Andreassen, at al. 2011). Senyawa fitokimia ini membantu melindungi sel dari kerusakan oksidatif yang disebabkan oleh radikal bebas.

Beberapa tanaman yang mengandung senyawa polifenol dan sering digunakan sebagai obat DM oleh masyarakat antara lain ; Ongkea (Mezzetia palviflora Becc.), Manggis (Gracinia mangostana Linn.), Lidah Buaya (Aloe vera Linn.), Brotowali (Tinospora crispa Linn.) dan Mengkudu (Morinda citrifolia Linn.) dengan kandungan polifenol masingmasing 20,24\% (Mufidah dkk. 2011), $16,21 \%$ (Hadriyono, K.R.P. 2011), $5,62 \%, \quad 4,34 \%$, dan $1,5 \%$ (J. Kloppenburgh-Versteegh, 2006).

Salah satu tanaman yang mengandung senyawa polifenol tersebut yakni ongkea, rebusan kulit batang secara empiris digunakan oleh masyarakat Bau-Bau Kabupaten Buton sebagai obat penurun kolesterol, pelangsing, obat DM dan obat tumor. Efek tersebut disebabkan oleh antioksidan dalam jumlah yang cukup tinggi didalamnya. Aktivitas antioksidan bermanfaat untuk melindungi sel dari berbagai keadaan fisiologi maupun patologik (Bucki, et al. 2003). Pengujian fitokimia klika ongkea menunjukkan adanya senyawa polifenol $20,24 \%$, flavanoid $1,76 \%$ dan tanin $26,46 \%$, dan pengujian aktivitas antiradikal bebas secara in vitro menunjukkan bahwa ekstrak klika ongkea mampu manangkap radikal bebas DPPH (Mufida dkk. 2008).

Adanya kerusakan progresif sel $\beta$ pankreas baik secara kualitatif maupun kuantitatif yang diawali oleh sebukan sel radang mononuklear pada pulau Langerhans mengindikasikan telah terjadi aktivasi sistem imun yang dapat disebabkan oleh berbagai faktor antara lain virus, bakteri dan rangsangan eksternal seperti streptozotocin (STZ) (Maedler, et al. 2001; Veld, 2009), Bila kerusakan berlanjut akan menyebabkan hiperglikemia yang akhirnya menimbulkan diabetes melitus. Keadaan hiperglikemia berhubungan dengan stres oksidatif dan patogenesis komplikasi DM, keadaan ini akan memicu peningkatan radikal bebas antara lain melalui reaksi glikasi non enzimatik (Aronoff, 2004; Silbernagl, 2007).

Mengingat potensi dan tingginya kandungan senyawa polifenol di dalam klika ongkea, maka telah dilakukan penelitian untuk mengembangkan ekstrak klika ongkea menjadi herbal terstandar yang berefek sebagai antihiperglikemia, dikaji berdasarkan peningkatan kadar insulin pada tikus putih jantan galur wistar yang diinduksi STZ $40 \mathrm{mg} / \mathrm{kg}$ BB tikus dosis tunggal secara i.p. Ekstrak klika ongkea diberikan dalam bentuk suspensi dengan dosis $100 \mathrm{mg} / \mathrm{kgBB}$ tikus dan $300 \mathrm{mg} / \mathrm{kgBB}$ tikus.

\section{METODE}

Jenis penelitian ini adalah eksperimental dengan rancangan modifikasi pretest postest randomized controlled group design. Dua kelompok penelitian yaitu kelompok kontrol (kelompok I; kontrol sehat, kelompok II ; kontrol sakit dan kelompok III ; kontrol obat) dan kelompok eksperimen (kelompok III, IV, dan V), dimana kelompok eksperimen diberikan treatment sedang kelompok kontrol tidak diberikan treatment.Penelitian dilaksanakan di laboratorium Fakultas Farmasi, 
Teknologi Rumah Sakit dan Informatika Universitas Megarezky bulan September sampai dengan Desember 2017.

Besar sampel ditentukan berdasarkan jumlah kelompok yakni 6 kelompok, setiap kelompok terdiri dari 20 ekor tikus, sehingga besar sampel pada penelitian ini sebanyak 120 ekor. Dimana 60 ekor diambil secara acak sebagai kontrol sehat 20 ekor, kontrol sakit 20 ekor dan kontrol obat 20 ekor. Sisa 60 ekor juga diambil secara acak untuk dimasukkan kedalam kelompok. Prosedur Penelitian

1. Perlakuan tikus

Kelompok I diberikan larutan koloidal Na. CMC 1\%, kelompok II diinduksi STZ $40 \mathrm{mg} / \mathrm{kgBB}$ tikus , kelompok III diinduksi STZ 40 $\mathrm{mg} / \mathrm{kgBB}$ tikus kemudian diberikan galvus $0,9 \mathrm{mg} / 200 \mathrm{gBB}$ tikus, kelompok IV diinduksi STZ 40 $\mathrm{mg} / \mathrm{kgBB}$ tikus kemudian diberikan suspensi ekstrak klika ongkea 100 $\mathrm{mg} / \mathrm{kgBB}$ tikus, kelompok V diinduksi STZ $40 \mathrm{mg} / \mathrm{kgBB}$ tikus kemudian diberikan suspensi ekstrak klika ongkea $300 \mathrm{mg} / \mathrm{kgBB}$ tikus dan kelompok VI pada hari minus 2 diberikan suspensi ekstrak klika ongkea $300 \mathrm{mg} / \mathrm{kgBB}$ tikus kemudian diinduksi STZ 40 $\mathrm{mg} / \mathrm{kgBB}$ tikus. Tikus masingmasing kelompok pada hari ke-1, ke-7, ke-14, ke-21 dan ke-28 dipuasakan terlebih dahulu kemudian diobservasi masingmasing 4 ekor.

2. Pemeriksaan kadar insulin

Pemeriksaan kadar insulin dilakukan 5 kali,yaitu 1 kali sebelum diinduksi STZ dan 4 kali setelah diinduksi STZ, yaitu hari ke-1, ke-7, ke-14, ke-21 dan ke-28, dengan mengambil darah secara intraorbita sebanyak 2 $\mathrm{ml}$ memakai pipa kapiler (Murnah, 2011) dan selanjutnya kadar insulin diukur dengan menggunakan Enzym-Linked Immuno Sorbent Assay (ELISA). Prinsip kerjanya berdasarkan jumlah ikatan antigenantibodi yang ditentukan dengan nilai absorbansi (Lequin, 2005).

\section{Analisis Data}

Data primer yang dikumpulkan pada penelitian ini meliputi hasil pengukuran kadar insulin tikus wistar setelah diinduksi STZ $40 \mathrm{mg} / \mathrm{kgBB}$ tikus dosis tunggal secara i.p dan setelah pemberian ekstrak klika ongkea $100 \mathrm{mg} / \mathrm{kgBB}$ dan $300 \mathrm{mg} / \mathrm{kgBB}$ tikus secara per oral setiap hari selama 21 hari, analisis data dilakukan dengan menggunakan uji $\mathrm{T}$ tidak berpasangan untuk membandingkan jumlah sel $\beta$ pankreas tikus antar kelompok.

\section{HASIL}

Hasil pengamatan kadar insulin tikus wistar yang diinduksi STZ sebagai berikut :

\begin{tabular}{ccccccc}
\hline $\begin{array}{c}\text { Observ } \\
\text { asi } \\
\text { hari ke }\end{array}$ & Kelompok I & $\begin{array}{c}\text { Kelompok } \\
\text { II }\end{array}$ & $\begin{array}{c}\text { Kelompok } \\
\text { III }\end{array}$ & $\begin{array}{c}\text { Kelompok } \\
\text { IV }\end{array}$ & Kelompok V & Kelompok \\
VI
\end{tabular}


Sumber : hasil olah data primer, 2017

Kadar insulin kelompok I, II, III, IV, sebagaimana pada gambar histogram $\mathrm{V}$ dan VI dipeoleh rerata kelompok

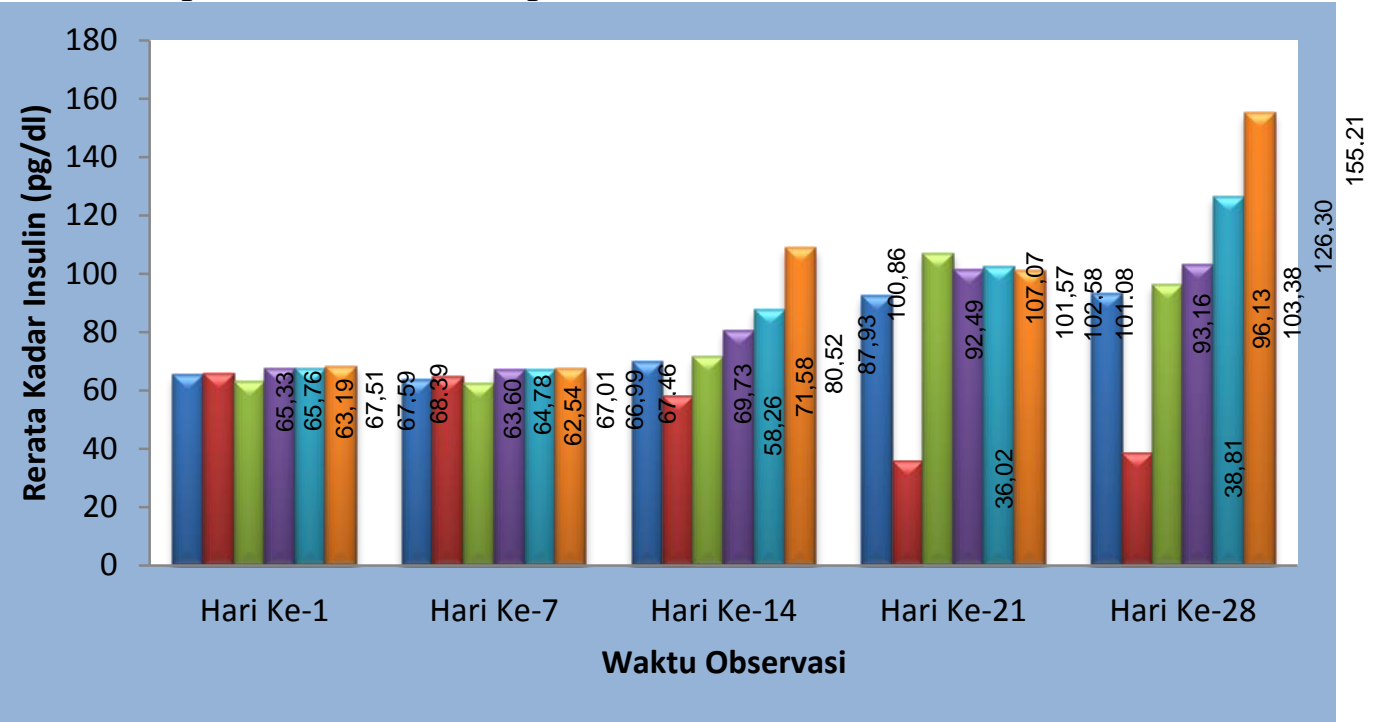

Sumber : hasil olah data primer, 2016.

\section{Keterangan :}

$\square \mathrm{Na} . \mathrm{CMC} 1 \% \mathrm{~b} / \mathrm{v} \longrightarrow$ STZ $40 \mathrm{mg} / \mathrm{kg} \mathrm{BB}$ tik $\square \quad$ Galvus 0,9 mg/200 g BB tikus

Ekstrak klika ongkea $100 \mathrm{mg} / \mathrm{kg}$ BB til $\quad$ Ekstrak klika ongkea 300 $\mathrm{mg} / \mathrm{kg} \mathrm{BB}$ tikus

Ekstrak klika ongkea $300 \mathrm{mg} / \mathrm{kg}$ BB tikus (proteksi)

Hasil rerata kadar insulin plasma tikus wistar pada hari ke-28 antara KI dengan KII, V dan KVI beda nyata dengan nilai $\mathrm{p}$ masing-masing 0,037 ; 0,026 dan $0,041<0,05$, sedangkan antara KI dengan KIII dan KIV tidak beda nyata dengan nilai $\mathrm{p}$ masingmasing 0,880 dan 0,632 > 0,05. Antara KII dengan KIII, KIV, KV dan KVI beda nyata dimana nilai $p$ masing-masing 0,$001 ; 0,003 ; 0,004$ dan 0,002 <0,05. Antara KIII dengan KIV tidak beda nyata dengan nilai $\mathrm{p}=$ $0,480>0,05$, tetapi KIII dengan KV dan KVI beda nyata dengan nilai $\mathrm{p}$ masing-masing 0,030 dan $0,050>$
0,05. Sementara itu antara KIV dengan KV dan KVI beda nyata dimana nilai $\mathrm{p}$ masing-masing 0,049 dan $0,047>0,05$ dan antara KV dengan KVI juga beda nyata dengan nilai $\mathrm{p}=0,014>0,05$. Hal ini menunjukkan bahwa pemberian ekstrak klika ongkea pada hari ke-28 berpengaruh terhadap peningkatan kadar insulin plasma tikus yang diinduksi dengan STZ (Ho ditolak dan Ha diterima) dan ada perbedaan pengaruh pemberian dosis bertingkat terhadap peningkatan kadar insulin plasma (Ho ditolak dan Ha diterima). 


\section{PEMBAHASAN}

Kadar insulin plasma pada hari ke-7 untuk KII, KIII, KIV, KV dan KVI mengalami penurunan setelah diinduksi STZ. Selanjutnya pada hari ke-14, ke-21 dan ke-28 kadar insulin plasma pada KII semakin menurun, hal ini disebabkan terjadi kerusakan sel $\beta$ pankreas sehingga mengalami penurunan. Hasil analisis menunjukkan bahwa antara KII dengan KIII, KIV, KV dan KVI terdapat perbedaan nyata $(\mathrm{p}<$ 0,05) mulai hari ke-14. Pada kelompok KIII, KIV, KV dan KVI menunjukkan peningkatan kadar insulin plasma dengan nilai rereta masing-masing kelompok 96,13 $\pm 7,05 ; \quad 103,38 \pm 17,21$; $126,30 \pm 33,71$ dan $155,21 \pm 40,43$ sedangkan pada KII menunjukkan penurunan kadar insulin plasma dengan rerata $38,81 \pm 19,47$. Hal ini menunjukkan bahwa pemberian ekstrak klika ongkea pada dosis 100 $\mathrm{mg} / \mathrm{kg}$ BB tikus dan $300 \mathrm{mg} / \mathrm{kg} \mathrm{BB}$ tikus dan $300 \mathrm{mg} / \mathrm{kg}$ BB tikus yang diberikan pada hari minus ke-2 mampu meningkatkan kadar insulin plasma.

Kecenderungan peningkatan kadar insulin plasma dalam penelitian ini menunjukkan bahwa ekstrak klinka ongkea mampu menghambat efek radikal bebas yang ditimbulkan oleh STZ dalam mengakibatkan hiperglikemia. Kecenderungan peningkatan kadar insulin plasma diduga terjadi karena senyawa aktif polifenol ekstrak klika ongkea mampu meningkatkan sekresi insulin oleh sel $\beta$ pankreas dan perannya sebagai antioksidan. Sebagai antioksidan senyawa aktif ekstrak klika ongkea menghambat efek radikal bebas yang disebabkan oleh
STZ sehingga kadar insulin plasma tidak terus menurun seperti yang terjadi pada kelompok KII.

Pada sel $\beta$ pankreas, reaksi STZ akan menimbulkan oksidasi peptida glutathion di dalam sel dan membentuk asam dialurik yang dapat menghasilkan radikal bebas berupa hidrogen peroksida $\left(\mathrm{H}_{2} \mathrm{O}_{2}\right)$, superoxide anion $\left(\mathrm{O}_{2}^{-}\right)$dan oxide nitric (NO) sehingga merusak rantai DNA sel $\beta$ pankreas. Rusaknya rantai DNA sel $\beta$ pankreas menyebabkan nekrosis dan mengakibatkan produksi serta sekresi insulin dari sel tersebut berkurang sehingga kadar insulin plasma menurun (Okamoto and Takasawa, 2002).

Pada sel yang memiliki reseptor insulin, radikal bebas dan ROS yang dihasilkan oleh STZ menyebabkan ROS lebih tinggi di dalam sel tersebut (Evans et al. 2007). ROS yang tinggi dalam sel yang memiliki reseptor insulin akan mengaktifasi berbagai jalur sinyal serin/threonin kinase. Jalur ini mampu memfosforilasi pada berbagai target termasuk kompleks Insulin Receptor-Substrate 1 (IRS1) dan reseptor insulin sehingga sensitifitas reseptor insulin menurun karena fosforilasi tyrosin kinase oleh insulin di reseptor insulin dan IRS1 menjadi berkurang.

Akibatnya phosphatidylinositol-3-kinase (PI3K) tidak dapat mengubah phospoinositid biposphat $\quad(\mathrm{PI}(3,4) \mathrm{P} 2) \quad$ menjadi phosphoinositid triphosphat (PI $(3,4,5) \mathrm{P} 3)$. Hal tersebut menyebabkan protein kinase $\mathrm{B}$ (PKB) tidak dapat bekerja untuk mengaktifkan GLUT-4 menuju transmembran sel sehingga glukosa tidak dapat diambil dari sirkulasi 
darah ke dalam sel yang memilki reseptor insulin (Evans, 2007).

Perlakuan dengan ekstrak klika ongkea diduga mampu berperan dalam mengembalikan homeostasis glukosa yang terganggu dengan menurunkan kadar glukosa darah dan cenderung meningkatkan kadar insulin plasma. Senyawa aktif ekstrak klika ongkea yang berperan dalam homeostasis glukosa darah ini belum diketahui secara jelas, namun diduga bahwa senyawa larut asetonair itu adalah golongan polifenol yang belum diketahui jenisnya. Senyawa aktif golongan polifenol ini yang berperan sebagai antioksidan yang dapat mencegah dan mengurangi radikal bebas dengan cara bereaksi langsung pada radikal bebas tersebut (Chattopadhyay et al. 2005).

Pada sel $\beta$ pankreas, diduga penghambatan radikal bebas akibat STZ oleh senyawa aktif ekstrak klika ongkea mengakibatkan sekresi insulin tetap terjadi sehingga kadar insulin plasma dalam penelitian ini cenderung meningkat. Selain itu, pada sel yang memiliki reseptor insulin, juga diduga bahwa penghambatan radikal bebas oleh senyawa aktif ekstrak klika ongkea menyebabkan komunikasi dalam sel untuk aktivasi dan sensitifitas reseptor insulin meningkat sehingga GLUT-4 dapat berfungsi mengangkut glukosa dari sirkulasi darah ke dalam sel dan kadar glukosa darah menurun. Glukosa darah yang diangkut akan mengalami metabolisme di dalam sel menjadi cadangan energi berupa glikogen di sel hati dan otot melalui proses glikogenesis serta menjadi lemak di sel adiposa melalui proses lipogenesis. Penambahan cadangan energi ini akan mengakibatkan terjadinya penambahan berat badan (Sherwood, 2004).

Berdasarkan pembahasan di atas, poilfenol yang terdapat dalam ekstrak klika ongkea sebagai antioksidan mampu menghambat dan mengurangi pengaruh radikal bebas yang dihasilkan oleh STZ. Pada sel $\beta$ pankreas, polifenol sebagai antioksidan cenderung meningkatkan sekresi insulin. Beberapa penelitian epidemiologi menunjukkan bahwa konsumsi buah yang kaya polifenol dapat menurunkan risiko diabetes melitus-2 (Muraki, et al. 2013). Suplementasi quercetin sebagai salah satu golongan polifenol akan memperbaiki status inflamasi, kadar insulin plasma dan kadar lemak pada tikus obesitas (Rivera, et al. 2008; Panchal, et al. 2012).

Berdasarkan hasil penelitian ini, induksi STZ dengan dosis 40 mg/kg BB tikus menyebabkan kadar insulin menurun, hal ini disebabkan oleh kerusakan sel $\beta$ pankreas. Penelitian yang dilakukan oleh Arora, et al. (2009) menunjukkan bahwa pemberian STZ $40 \mathrm{mg} / \mathrm{kg}$ BB dosis tunggal secara i.p menyebabkan hiperglikemia pada minggu pertama dan masih bertahan sampai minggu kelima. Potensi insulin dapat ditingkatkan dengan memperbaiki kerusakan sel $\beta$ pankreas yakni memberikan antioksidan seperti polifenol. Beberapa penelitian terdahulu telah membuktikan bahwa pemberian bahan alam yang mengandung polifenol dapat memperbaiki kerusakan sel $\beta$ pankreas.

Peningkatan kadar insulin plasma pada kelompok KIV, KV dan KVI disebabkan oleh senyawa polifenol yang berperan sebagai 
antioksidan dan dapat memperbaiki kerusakan sel $\beta$ pankreas akibat radikal bebas. Perbaikan (regenerasi) kerusakan sel $\beta$ pankreas akan memperbaiki fungsi sel beta pankreas, sehingga produksi insulin plasma menjadi normal.

Kadar insulin plasma pada hari ke-28 pada kelompok KIV, KV dan KVI terdapat perbedaan secara nyata $(\mathrm{p}<0,05)$ dengan rerata kadar insulin plasma masing-masing kelompok 103,38 $\pm 17,21$; $126,30 \pm 33,71$ dan $155,21 \pm 40,43$. Hal ini menunjukkan bahwa pemberian ektstrak klika ongkea pada dosis 100 $\mathrm{mg} / \mathrm{kgBB}, 300 \mathrm{mg} / \mathrm{kgBB}$ dan 300 $\mathrm{mg} / \mathrm{kgBB}$ yang diberikan pada hari minus 2 memilki kemampuan yang berbeda terhadap peningkatan kadar insulin plasma pada hari ke-28. Pemberian ekstrak klika ongkea 300 $\mathrm{mg} / \mathrm{kg}$ BB pada hari minus 2 memberikan peningkatan kadar insulin yang paling tinggi di hari ke28 , yaitu $155,21 \pm 40,43$. Hal ini menunjukkan bahwa pemberian ekstrak klika ongke $300 \mathrm{mg} / \mathrm{kg}$ BB pada hari minus 2 efektif memberikan perlindungan terhadap sel $\beta$ pankreas dari pengaruh STZ . Hal ini diduga polifenol yang tedapat ekstrak klika ongkea mengaktifkan enzin antioksidan seperti superoksid dismutase, katalase dan glutation peroksidase serta mencegah terjadinya stres oksidatif, sehingga kerusakan sel $\beta$ pankreas dapat diminimalisir.

Kadar insulin plasma kelompok KV dan KVI berbeda nyata dengan kelompok KIII yaitu kelompok yang mendapat obat galvus, dengan nilai $\mathrm{p}$ masing-masing $<0,05$, dimana rerata kadar insulin plasma kelompok KV dan KVI adalah 126,30 $\pm 33,71$ dan $155,21 \pm 40,43$, sedangkan kelompok KIII memiliki rerata kadar insulin $96,13 \pm 7,05$. Dengan demikian dapat dikatakan bahwa ekstrak klika ongkea memiliki efek yang lebih tinggi dibanding dengan obat galvus dalam meningkatkan kadar insulin plasma.

\section{KESIMPULAN}

1. Pemberian ekstrak klika ongkea berpengaruh terhadap peningkatan kadar insulin plasma tikus wistar yang diinduksi STZ.

2. Ada perbedaan pengaruh pemberian dosis bertingkat ekstrak klika ongkea terhadap peningkatan kadar insulin plasma tikus wistar yang diinduksi STZ.

\section{SARAN}

Pengujian aktivitas ekstrak klika ongkea terhadap Reactive Oxygen Species dan resistensi insulin.

\section{DAFTAR PUSTAKA}

Abdallah H., Farag MA., Abdel-Naim AB., Gharieb SA., and Abdel-Satta EA. 2015. Mechanistic Evidence of Viscum schimperi (Viscaceae)

Antihyperglycemic Activity: From a Bioactivity-guided Approach to Comprehensive Metabolite Profiling. Phytother Res. DOI10.1002/ptr.5424.

Andreasseen and Anderson, J.W. 2011. Lipoid Acid Improves Survival in Transgenik Mouse Models of Hunting's Disease. J. Neuroreport. 12 : 3371-3373.

Aronoff, S.L. 2004. Glucose Metabolism and Regulation 
Beyond Insulin and Glucagon. J. Diab. 3(17):8390.

Arora, S. Ojha, S. K., Vohora, D. 2009. Characterisation of Streptozotocin Induced Diabetes Mellitus in Swiss Albino Mice. Glob. J. of Pharmacol. 3(2):81-84.

Bucki, R., Pastore, J.J., Giraud, F., Sulpice, J.C. and Jenmey, P.A. 2003. Flavanoid Inhibition of Platelet Procoatjupant Activity and Phosphoinositide Synthesis. Journal of Thrombosis and Haemostasis, 1: 1820.

Chattopadhyay. R.R. \& Bandyopadhyay, M. 2005. Possible mechanism of hepatoprotective activity of Azadirachta indica leaf extract against paracetamol induced hepato damage in rat : part III. Indian $J$ Pharmacol, 37(3), 184-185.

Hadriyono, K. R. P. 2011. Karakter Kulit Manggis, Kadar Polifenol dan Potensi Antioksidan Kulit Manggis (Garcinia mangostana Linn.) Pada Berbagai Umur Buah dan Setelah Buah Dipanen, Departemen Agronomi dan Hortikultura, Fakultas Pertanian IPB Bogor. 47-53.

J. Kloppenburgh-Versteegh, 2006. Tanaman Berkhasiat Indonesia, volume 1. Alih bahasa ; J. Soegiri dan Nawangsari. Jakarta.

Kahkonen, M.P., A.I.Hopia, H.J. Vuorela, J.P. Rauha, K. Pihlaja, T.S. Kujala and M. Heinonen. 2009. Antioxidant
Activity of Plant Extracts Containing Phenolic Compounds. J. of Agriculture and Food Chemestry. 47 : 3954-3962.

Lequin, R. M. 2005. Enzym Immuno Assay (EIA)/Enzym-Linked Immunosorbent Assay (ELISA). Clinical Chemistry, 51 (12):15-18.

Maedler, K., Spinas, G. A., Lehmann, R., Sergeev, P., Weber, M. and Fontana, A. 2001. Glucose Induces Beta Cell Apoptosis Via Up Regulation of the Fas Receptor in Human Islets. J. Diab. 50:8390.

Mufidah, 2011. Aktivitas Antiaterosklerosis Ekstrak Terstandar Klika Ongkea (Mezzetia parviflora Becc.) Pada Tikus Wistar yang Diberi Asupan Kolesterol : Kajian Efek Antioksidan dan Antikolesterol Terhadap Penghambatan MCP-1 dan Disfungsi Endotel. Disertasi Pada Program S3 Program Pascasarjana Universitas Hasanuddin. 45-55.

Muraki, I., Imamura, F., Manson, JE., Hu, FB., Willett, WC. 2013. Fruit Consumption and Risk of Type 2 Diabetes : Results From Three Prospective Longitudinal Cohort Studies. BMJ 347 : f5001. 10.1136/bmj.5001.

Murkhejee, P.K., Maiti, K., Murkhejee, K., Houghton, P.J. 2006. Leads from Indian Plants with Hypoglycemic Potentials.

$\mathrm{J}$. Ethnopharmacol. 106 : 1-28. 
Nurdiana, NP., Setyawati dan M. Ali. 1998. Efek Streptozotozin Sebagai Bahan Diabetogenik pada Tikus Wistar dengan Cara Pemberian Intraperitonial dan Intravena. Majalah Kedokteran Universitas Brawijaya. Vol XIV, No 2 : hal 66-67.

Okamoto, H. \& Takasawa, S. 2002. Recent advances in the okamoto model : The Cd38 cyclic ADP-Ribose signal system and the regenerating gene protein (Reg)-Reg receptor system in $\beta$-cells. Diabetes, 51(3), 462-473.

Panchal, SK., Poudyal, H., Brown, L. 2012. Quercetin Ameliorates Cardiovascular, Hepatic and Metabolic Changes in Diet-Induced Metabolic
Syndrome in Rats. J Nutr 142 : 1026-1032.

Rivera, L., Moron, R., Sanchez, M., Zarzuelo, A., Galisteo, M. 2008. Quercetin ameliorates Metabolic Syndrome and Improves the Inflammatory Status in Obese Zucker Rats. Obesity 16 : 2081-2087.

Sherwood, L. 2004. Human physiology : from cells to systems. 5th ed. Thomson learning, Inc. Brooks.

Silbernagl, S., and Lang, F. 2007. Atlas Berwarna Patofisiologi. Diterjemahkan oleh Iwan S., dan Iqbal M. Penerbit Buku Kedokteran EGC. Jakarta. 286-296.

Suharmiati. 2003. Pengujian Bioaktivitas Anti Diabetes Mellitus Tanaman Obat. Cermin Dunia Kedokteran. 140;8-13. 